\title{
The Lexicalization of "na $X$ " in Mandarin Chinese and Its Teaching Chinese as a Foreign Language
}

\author{
Hong $\mathrm{Li}^{1,2, *}$ \\ ${ }^{1}$ School of Humanity, Zhejiang University, Hangzhou, Zhejiang 310028, China, \\ ${ }^{2}$ School of Science and Technology, Guizhou University, Guiyang, Guizhou 550001, China \\ *Corresponding author. Email: 229325944@qq.com
}

\begin{abstract}
The word "na X" in mandarin Chinese, which is formed by the combination of the interrogative morpheme na and the adjacent morpheme $X$, cannot be inferred from its composition, causing serious difficulties in reading comprehension for foreign students. Therefore, it is necessary to find effective ways for foreign students to avoid the use errors. This paper first analyzes the lexicalized performance, lexicalized mechanism, and subjectivization level of na $\mathrm{X}$ in detail. Secondly, it puts forward practical suggestions on textbook vocabulary interpretation, teachers' awareness of scientific research and classroom teaching methods. It is found that the investigation of the lexicalization process of na X in Mandarin not only provides evidence support for the lexicalization of na $\mathrm{X}$, but also contributes to the positive effect of na $\mathrm{X}$ in teaching Chinese as a foreign language.

Keywords: na X, lexicalization, teaching Chinese as a foreign language, subjectivization, errors
\end{abstract}

\section{INTRODUCTION}

Vocabulary learning is an important part of teaching Chinese as a foreign language. It is essential for non-native Chinese students to understand the meaning and usage of vocabulary correctly. In modern Chinese, the interrogative morpheme na can be combined with other monosyllabic or disyllabic morphemes to form the word na X, such as na li (哪里), na pa (哪怕), na men zi (哪门子), etc. na X not only expresses the usage of question or rhetorical question, but also the non-question usage. Here are examples.

(1) yī gè mài chàng de gū niáng,dú nă mén zǐ shū? ${ }^{1}$

A singing girl read what book.

'A singing girl doesn't need to read.'

(2) wǒ zhī dào,nǐ nă lǐ huì ài tā ne?

I know you where will love him

'I know you will not love him.'

(3) nǎ pà shì yī diăn xiǎo quē diăn,yě yīng dāng shuō!

Even if is a little small mistake also hould say.

'Even if it is a small defect, it should be said!'

na men zi in (1) means negative, conveying the implicit meaning that the speaker thinks a girl who lives on singing does not need to read books. na li in (2) expresses the speaker's conviction that the other person won't love him. na pa in (3) means even if ${ }^{2}$, which is a concession conjunction that assumes unrealistic situations. The meaning of na $\mathrm{X}$ in the above three examples cannot be inferred from the literal meaning of na and $X$.

\footnotetext{
${ }^{1}$ The corpus of this article comes from the Chinese Corpus of the Center for Chinese Linguistics of Peking University.

2 According to Modern Chinese Dictionary, $n a \mathrm{X}$ is a conjunction, which means even if, that means to admit a certain fact temporarily.
}

Semantically, it shows the speaker's strong subjective cognition and attitude, presenting the characteristics of semantic integrity and deviation. This shows that the internal tightness of na $\mathrm{X}$ is equivalent to a word and performs different functions in different syntactic positions, such as na men zi as an attribute, na li as an adverbial, and na pa as a conjunction. However, the already-formed word na $\mathrm{X}$ often causes serious reading barriers for international students, so finding suitable teaching methods to enable international students to master the meaning and usage of the word na $X$ is of great significance and value.

Some scholars have done case studies on the lexicalization of na X. For example, Liu Hongni (2010) analyzed the lexicalization of na pa, pointing out that na pa is derived from the lexicalization of the adverb na and the verb pa which is a non-syntactic structure[1]; Zhang Xuemei (2015) carried on an investigation of na men zi, believing that na men zi is derived from the lexicalization of the interrogative pronoun na and the quantifier structure men $\mathrm{zi}[2]$. Based on the existing researches, this paper attempts to investigate the lexicalization performance of na X, study the lexicalization mechanism of it, and divide its subjectivization level. According to this level, teaching methods and strategies of na $\mathrm{X}$ in teaching Chinese as a foreign language are drawn up.

\section{THE LEXICALIZATION PERFORMANCE OF $n a X$}

In order to make sense of the lexicalization performance of $n a X$, we first examine the nature of the morpheme $n a$ and the composition of the morpheme $X$, and then discuss the 
lexicalization criteria of $n a X$.

\subsection{Investigation of na and $X$}

There have always been differences in the part of speech attribution of interrogative pronouns. One view is that words which can replace unknown things in interrogative sentences are interrogative pronouns. Zhu Dexi (1982) believes that $n a$ is an interrogative pronoun[3] $n a$ in (4) followed by a quantifier indicates choice. $n a$ in (5) used in a rhetorical question is to emphasize the negation of something.

(4) zhè jǐ běn shū lǐ nă běn zuì hăo?

this books in which the best.

'Which one of these books is the best?'

(5) zhè me dà de dì fâng,nă néng yī tiān jiù zǒu biàn?

So big place how can one day walk around.

'How can you travel around such a big place in one day?'

The interrogative pronoun $n a$ in (5) is followed by the modal verb neng (能), which means that it is impossible to travel in such a big place in one day.

The second opinion, for example, Lv Shuxiang (1980) holds that $n a$ before a verb is regarded as a pronoun or an adverb according to different syntactic environments [4].

(6) nă shì nǐ jiā?

where is you home?

'Which is your home?'

(7) nă néng suí biàn làng fèi?

how can casual waste?

'How can it be casually wasted?'

$n a$ in the above examples is placed before the judgment verb $s h i$ (是) and the modal verb neng respectively. $n a$ in (6) is a pronoun, used in interrogative sentences, which means that the speaker requires the other speaker to give an exact reply. $n a$ in (7) is an adverb, used in a rhetorical context, to express the negative meaning that it cannot be wasted casually.

We agree with what Mr. Lv pointed out that interrogative words used before verbs have the function of pronouns or adverbs. The question-word should be classified into different parts of speech according to different syntactic positions and different syntactic environments. Used in front of the quantifier structure, $n a$ is regarded as a pronoun no matter it expresses interrogative or non-interrogative usage; when used in front of verbs, $n a$ exhibits the function of a pronoun in the interrogative context and reflects its adverb characteristics in the rhetorical context. Therefore, we believe that $n a$ is both an interrogative pronoun and an interrogative adverb.

The Modern Chinese Dictionary (7th edition) contains seven words of $n a X$, such as na ge (哪个), na Xie (哪些), na hui (哪会), na yang (哪样), na men zi, na li, na pa, etc. [5]. Among them, $X$ can be a quantifier (8-12), a position noun (13) or a mental verb (14).

(8) tā méi fă pàn duàn nă gè gèng jìn yú shì shí.

He cannot judge which closer fact.

'He cannot judge which one is closer to the facts.'

(9) kě shì wǒ men bú rèn shí nă xiē shì nǐ men chăng lǐ zì jiā rén ya!

But we not know which are you factory in family members.

'But we don't know which ones are your own family members in your factory!'

(10) š̌ hòu hái bú zhī nă huì ér jiù bèi rén jiā jué chū lái! death after no know when somebody dig out.

'He may be dug out sometime after death!'

(11) bù hăo, bù hăo, hăo nă yang!

no good no good good which.

'It's not good at all!'

(12) zán jǐ gè shàng xiàn lǐ qù suàn shì nă mén zǐ ya!

We up county in go is what.

'How can we go to the County?'

(13) Liú Sū gū shēn liú zài bā ér dùn dào,nă lǐ zhī dào shén me.

Liu Su alone stay Palton Road where know what.

'Liu Su stays alone in Palton Road, knowing nothing.'

(14) nă pà tā chōu wǒ jǐ gè zuǐ bā ne,wǒ yě lè yì jiē shòu!

Even if he slap I several mouth I also happy accept

'Even if he slapped me, I would be gladly accept it!'

$n a X$ in (8-13) is an interrogative pronoun. na pa in (14) is a conjunction, followed by a complete clause.

\subsection{The lexicalization standard of na $X$}

The morphemes of $n a$ and $X$ in $n a \quad X$ have been agglutinated, that is, agglutination occurs when two or more terms originally distinct, but frequently joined together syntagmatically in sentences, merge into a single unit which is either unanalyzable or difficult to analyze[6]. From a diachronic perspective, Dong Xiufang (2007) put forward that lexicalization is the process of non-word units such as phrases gradually solidifying and becoming compact to form words[7]. With reference to Dong Xiufang's lexicalization standards[8] when discussing the lexicalization of $X$ shuo, we believe that there are two lexicalization standards for $n a X$. First, in terms of structure, $n a X$ is used as a unit in a sentence, and other elements cannot be inserted in the combination. Second, semantically, the meaning of $n a X$ cannot be inferred from the composition of the two elements. Based on this, the lexicalization of the words $n a X$ included in Modern Chinese are investigated one by one.

1. Whether other components can be inserted into the combined structure

Take na yang as an example to examine the performance of components-inserting.

(11)' *b. bù hăo,bù hăo,hăo nă yī yàng!

*c. bù hăo,bù hăo,hăo nă gè yàng!

In Example (11)', the sentence is an unqualified expression after inserting the morpheme $y i$ or ge in the object argument na yang. This shows that other components cannot be inserted into na yang, which has been used as a solidified unit. The remaining six $n a X$ are tested in the same method as follows.

(8)' tā méi fă pàn duàn nă yī gè gèng jìn yú shì shí.

(9)' kě shì wǒ men bú rèn shí nă yī xiē shì nǐ men chăng lǐ zì jiā rén ya! 
$(10)^{\prime} *$ sǐ hòu hái bú zhī nă yī huì ér jiù bèi rén jiā jué chū lái!

$(12)^{\prime}$ * zán jǐ gè shàng xiàn lǐ qù suàn shì nă yī mén zǐ ya!

$(13)^{\prime}$ * liú sū gū shēn liú zài bā ér dùn dào,nă yi lǐ zhī dào shén me.

$(14)^{\prime *}$ nă hài pà tā chōu wǒ jǐ gè zuǐ bā ne,wǒ yě lè yì jiē shòu!

No other components can be inserted between $n a$ hui, na men zi, na li, na pa, just like na yang, which meets the first criterion of lexicalization. However, after the morpheme $y i$ is inserted between $n a$ ge and na xie, the sentence expression can still be accepted, which does not accord to the lexicalization standard, so na ge and na xie has not been formed into a word.

2. Whether the semantics are unpredictable

If $n a X$ is formed into a word, the meaning of it is no longer a simple addition of the meanings of $n a$ and $x$, because na $X$ has overall meaning and function. We still take na yang as an example to investigate its semantic performance. hao na yang in (11) means that nothing is good. This semantic connotation can be sensed by context, but cannot be inferred from the meanings of $n a$ and $X$. This is also in line with the definition of lexicalization by Brinton and Traugott (2005): Lexicalization is the change whereby in certain linguistic contexts speakers use a syntactic construction or word formation as a new contentful form with formal and semantic properties that are not completely derivable or predictable from the constituents of the construction or the word formation pattern"[9]. Based on this, the semantic performance of other six $n a X$ are also investigated, and there were two situations. One situation is that the meaning of $n a X$ cannot be inferred from the literal structure, and the semantics are unpredictable in form and meaning. For example, na hui er in (10) means a certain time; na men $z i$ in (12) means what, which is irrelevant with the meaning of the quantifier men and its suffix $z i$; na $l i$ in (13) is a negative universal quantifier expression; $n a$ and $p a$ in (14) have lost their original lexical meaning, and na pa is no longer a question, but is used as a conjunction, equals to even if. Another case is that the meaning can be inferred from its constituent components because the internal structure of $n a$ $X$ is transparent. For example, na ge in (8) means which one, and na Xie in (9) means which person.

After testing $n a X$ included in Modern Chinese Dictionary according to the two lexicalization criteria we proposed, we found that na hui, na yang, na men zi, na li, na pa meets the two reference standards, having been lexicalized to a word. na ge and na xie does not meet these two standards, not having been lexicalized.

\section{THE LEXICALIZATION MECHANISM OF na $X$}

\subsection{Approach principle}

$n a$ is widely used in ancient Chinese and is one of the most frequently used question words when asking questions. $n a$ and $X$ are two linguistic units at different syntactic levels. The adjacency of the syntactic position provides objective syntactic conditions for the adhesion of $n a X$. Language users are accustomed to treating two adjacent language components as a whole, which provides a psychological basis for vocabulary chunks. During the high-frequency use of $n a X, n a$ and $X$ can no longer be modified by other modifiers, the structural rationale is gradually blurred, and the interdependence gradually increases, thus forming a psychological "chunking" [10]. At the same time, based on the requirements of prosody, the two adjacent components of $n a$ and $X$ form a dimeter, which is easy to combine to form a prosodic word [11]. For example, the lexicalization of $n a$ li and na yang appeared in the history of Chinese in the Five Dynasties (15) and Qing Dynasty (16) when disyllabic words were prevalent.

(15) fēng yuē: “jiāng xī nă lị̌?" duì yuē: "shí shuāng." Feng said Jiangxi where reply shi shuang

'Feng said: "Where is Jiangxi?" He replied: "Shishuang.", (16) shī fù, nǐ shuō rén lún zhèng dào,què shì nă yàng rén lún?

Master you said humanity righteous but is what humanity

'Master, you say that human relations are righteous, but what kind of human relations is it?'

As for the three-syllable $n a$ men $z i, z i$ in it is an affix, which is an implicit component of the rhythm. The virtual meaning of $z i$ can only be added to the main word men to participate in lexicalization.

\subsection{Ellipsis and conventionalization}

In the combination of " $n a+$ quantity structure", $n a$ was originally followed by the quantity structure or the quantity-noun structure, and the number $y i$ is usually used before the quantifier. Here are examples.

(17) shuō bú dìng nă yī huì ér jiù huì sǐ ér fù sū ā!

Maybe when will die revover!

'Maybe it will die and recover soon!'

(18) tā shì nǐ nà yī mén zĭ de 'năi năi ',nǐ men zhè me xiào jìng tā?

She is you which nainai you so respect her.

'She is not your grandma, why do you respect him so much?'

The existence of the numeral $y i$ leads to the fact that $n a$ and $X$ are not adjacently connected in syntactic sequence, and the structural relationship is not close enough. na men $z i$ in (18) is used as a substantive component in the sentence, and it is only used in conjunction with the following kinship nouns. In the process of language use, the numeral $y i$ slowly falls off and is omitted, which provides the structural relationship of adjacent sequences for $n a$ and $X$. Examples are as follows.

(19) bú zhī nă huì ér cóng zhāo pái hòu zuàn chū gè xiăo hái lái.

Not know when from signboard behind come out a child come.

'I don't know when a child came out of the sign.' 
(20) nǐ zhe nă mén zí jí ne?

You what anxious

'What are you so anxious about?'

na hui in (19) is a virtual meaning with low semantic transparency. na men $z i$ in (20) presents the negative evaluation of the speaker's rebuttal interpreting, which has a high degree of conventionalization[12]. Its meaning is no longer transparent, that is, it can be clearly interpreted without reference to the context.

\subsection{Reanalysis}

na $p a$, a cross-layer structure, requires a specific syntactic environment when lexicalizing. Only when $n a p a$ is at the beginning of the whole sentence or the latter sentence of the complex sentence, can it be reanalyzed to form the structure of [[na pa][VP], [VP ]] or [[VP],[na pa] [VP]], and then $n a$ pa has been lexicalized to be a conjunction $^{[1] 142-150}$. We take na pa placed at the beginning of the whole sentence as an example to show the process of reanalysis.

(21) zhī yào ér zĭ tiáo lǐ dé shēn tǐ hăo le,nă pà shăo le sūn Zǐ?

As long as son take care of body good where fear less grandson

'As long as my son is in good health, don't worry about not having a grandson.'

(22) nă pà shuō cuò le,wǒ bú guài nǐ.

Even if say wrong I not blame you

'Even if you are wrong, I don't blame you.'

$n a p a$ in (21) is in the structure of [ $n a[p a[\mathrm{VP}]]]$, [VP]], where $p a$ is the main verb in the sentence, which is closely related to the VP syntax. The meaning of $n a p a$ can be inferred from the meaning of its constituent elements, meaning that don't worry about. $p a$ in (22) has been separated from the closely syntactic relationship with VP,

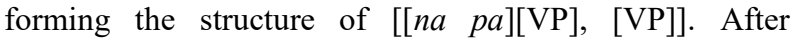
structural reanalysis, $p a$ is no longer the main verb in the sentence, which combines with $n a$ to form the word $n a p a$ with no substantial meaning, playing a concessional connection role between the clauses.

\section{THE SUBJECTIVIZATION LEVEL OF $n a X$ AND TEACHING CHINESE AS A FOREIGN LANGUAGE}

\subsection{The level of subjectivization of na $X$}

In the process of lexicalization,the corresponding language structure will also evolve in language expression, bringing subjective meaning. Subjectivity means that the speaker embodies his own position, attitude, or emotion in the content of the speech, leaving a subjective mark of "self" [13]. The lexicalization of $n a X$ often reflects the increase in the speaker's empathy towards the subject, which makes the semantics of $n a X$ more unpredictable. Correspondingly, the rationale between the two components becomes weaker and the structure becomes more solidified.

According to the subjectivization degree of $n a X, n a X$ can be divided into three levels of subjectivization: high, medium and low.

1. The high-level subjectivization

$n a X$ is an explicit subjective component, which only conveys the speaker's subjective emotions and attitudes.

(23) nǐ chī nă mén zĭ de cù ne.

You eat what vinegar

'What are you jealous about?'

(24) nă pà tā shì wǒ de dì dì,wǒ yě bú qíng yuàn de.

Even if he is my brother I also not willing

'Even if he is my younger brother, I am reluctant.'

$n a$ men $z i$ in (23) carries speakers' subjective assessment that there is no need to be jealous. na pa in (24) does not have a conceptual meaning, but embodies the procedural meaning of the concessional semantic relationship between two clauses ${ }^{3}$. The procedural information contained can lead the listener to pay attention to the existing relationship in the contextual hypothesis, clarifying the speaker's discourse intention

2. The middle-level subjectivization

There are two kinds of $n a X$. One shows subjective meaning, and the other is non-subjective.

(25) a. zuò nă yàng yō!

Do what?

'You don't have to do that!'

b. zhè shì gè nă yang zhào tóu?

This is a what sign?

'What kind of sign is this?'

(26) a. nǐ rén yě yǒu zhè me dà le,nă lǐ qù bú dé?

You also have so big where go cannot?

'You are not a child, where can't you go?'

b. nǐ shàng nă lǐ qù le,zěn me bă yī shuāng xié nòng zāng le?

You up where go why a pair shoe dirty?

'Where have you been to and how did you put a pair of shoes dirty?'

na yang in (25a) expresses the speaker's subjective perception that nothing needs to be done. na li in (26a) expresses the speaker's helpless subjective attitude that you can go anywhere. na yang and na li in (25b) and (26b) are still in the context of real questions that require the listener to answer.

3. The low-level subjectivization

There is no implantation of subjective elements into $n a X$.

(27) nă huì ér xiăng qù dōu kě yǐ

when want go can.

'You can go any time you want.'

For different levels of lexicalization teaching, Chinese teachers should adopt corresponding effective teaching methods and strategies to avoid language errors caused by foreign students in the process of using it.

\footnotetext{
3 The so-called procedural meaning means that the discourse marker does not affect the truth value of the proposition, but only affects the understanding of the relationship between discourse units.
} 


\section{2. na $X$ in Teaching Chinese as a Foreign Language}

\author{
4.2.1. Enlightenment to the interpretation of \\ vocabulary in teaching materials
}

At present, most textbooks of teaching Chinese as a foreign language use the "phonetic-interpretation" method for vocabulary annotation, which is not comprehensive enough to explain the syntactic functions of words. Chinese words have formed their own unique evolution trajectory in the process of social development. A word may derive multiple semantics and have multiple grammatical functions. This does not completely correspond to the meaning and scope of application marked in the textbook. Moreover, some new words are generated in a special syntactic environment through high-frequency use. This development process cannot be understood by students only through "phonetic-interpretation", let alone use words freely. We believe that Chinese teaching materials for foreigners can learn from the ontological research results of Chinese vocabulary and complete the compilation of the vocabulary in the textbook from the perspective of lexicalization and subjectivization, so that students can learn more vocabulary information during self-study, and the textbook compilation will be more scientific and effective.

For $n a$ in the low-level subjectivization, the "phonetic-paraphrase-example sentence" method for vocabulary annotation can be appropriately adopted to help students understand the meaning of words, be familiar with the words' syntax environment, and reduce students' confusion. $n a$ in medium-level subjectivization not only adopts the annotation method of "phonetic-paraphrase-example sentence", it also needs clear interpretation and explanation for the development and evolution of vocabulary. For example, the following content can be added after the original note of na yang in the textbook. The lexicalization of na yang appeared in the Qing Dynasty when disyllabic words were prevalent, and the original meaning of it was "the nature or state of things". Used in rhetorical questions in modern Chinese, na yang is often placed after the predicate component and its semantics are blurred, mainly expressing the subjective attitude of the speaker. For $n a$ in high-level subjectivization, it is necessary to add their lexical diachronic analysis after the original annotation. For example, before the lexicalization of na pa, na leads to a question and $p a$ is a verb with the original meaning of "fear". Before the lexicalization of $n a p a$, the source structure is [na[pa[VP]]], [VP]]. During the process of lexicalization, $p a$ gradually dissociated from the close syntactic relationship with VP, and then the structure [[ $n a$ $p a][\mathrm{VP}],[\mathrm{VP}]]$ was formed. In this case, $n a$ pa has been reanalyzed, and was transformed into a conjunction in the late Qing Dynasty, which means even if, is often placed at the beginning of the sentence, guiding the adverbial clause of concession.

By increasing the annotation content of the lexical ontology research, international students have a certain understanding of the history of Chinese vocabulary development, which helps to enhance their understanding of Chinese vocabulary structure and can also deepen their understanding of what they have learned.

\subsubsection{Cultivation of teachers' scientific research awareness}

When teaching Chinese as a foreign language, we strive to enable students to accurately understand the meaning of $n a$ $X$, and require teachers to fully understand the meaning and usage of na $X$, including its morphemes, internal structural features between morphemes, the syntactic environment, and discourse functions, etc. Only in this way, teachers can provide students detailed analysis and meticulous guidance.

The problem faced in teaching Chinese as a foreign language is that although Chinese teachers are all full-time teachers of Chinese majors, they have insufficient research on the ontology of Chinese language and characters. Some teachers lack of knowledge of Chinese history, have no ability to examine the diachronic development of vocabulary, and cannot have a complete grasp of the semantic performance of vocabulary. So, when teaching the lexicalized vocabulary, teachers may not be able to trace the development of vocabulary to its origin and fail to extend its semantic development during the teaching process. Therefore, it is difficult for students to fully understand the meaning of words and their usage.

We believe that the study of vocabulary evolution will guide and restrict the quality of teaching Chinese as a foreign language, because only when the characteristics of Chinese are fully understood can teachers teach Chinese to non-native Chinese speakers in a clear and concise manner. Generally speaking, most Chinese vocabulary teaching stays at the synchronic level of interpretation teaching, which is effective for $n a X$ in low-level or some intermediate-level subjectivization, but for $n a \quad X$ in high-level subjectivization, it is necessary to understand the vocabulary evolution from a diachronic perspective. Teachers need to understand the history and evolution of vocabulary to better teach vocabulary to students. Therefore, it is extremely important to improve the scientific research awareness of teachers who teaches Chinese as a foreign language.

\subsubsection{Traceability teaching method}

Chinese characters are ideographic characters that integrate sound, form and meaning, and each Chinese character has its own independent meaning. In teaching Chinese as a foreign language, morpheme teaching cannot be ignored, because morpheme is the constituent element of Chinese vocabulary, and morpheme meaning is the basis of word 
meaning. Although the meaning of most words is not necessarily a simple superposition of morphemes, learning morphemes is very important for understanding words. Even $n a X$ in high-level subjectivization with extremely low semantic transparency cannot ignore the meaning of its constituent morphemes. The meaning of the word often has a deep relationship with the meaning of the morpheme, and its evolution path can be discovered by doing some exploration. For example, through morpheme analysis, we know that the morpheme $n a$ in $n a p a$ is located before the verb $p a$, which reflects the function of adverbs. Adverbs often modify verbs, so the verb $p a$ gradually separates from the VP, and approaches the adverbs $n a$, and $n a p a$ eventually lexicalized to a new word.

In class, teachers should first introduce and emphasize the overall meaning of vocabulary to avoid that foreign students understand the words directly from the literal meaning and cause usage errors. Then the composition of words should be reasonably analyzed, which helps students understand the meaning of words composition. Finally, the vocabulary will be explained in a tracing style, and the evolution path of the vocabulary will be clearly presented. This will undoubtedly be an effective way for international students to learn Chinese vocabulary.

\section{CONCLUSION}

$n a X$ is lexicalized to form interrogative pronouns and concession conjunctions, among which na has the functions of interrogative pronouns and interrogative adverbs. The adjacent morphemes $n a$ and $X$ in the syntactic position are combined into words with integral meaning under the language mechanism of approach principle, omission of conventions, reanalysis, etc., and present different degrees of subjective expression in the process. For the different subjectivization level of $n a X$, effective teaching methods and strategies should be adopted in teaching Chinese as a foreign language. Therefore, exploring the performance of the Chinese interrogative pronoun $n a$ and the adjacent language components solidified into words not only provides evidence for the lexicalization of $n a \quad X$, and more importantly, the investigation of the lexicalization process contributes to the positive effect of $n a X$ in teaching Chinese as a foreign language. The teaching effect will be improved through the improvement of the interpretation of textbook words, the enhancement of teachers' scientific research awareness, and the application of traceability teaching methods, so as to avoid errors in the process of language use by foreign students.

\section{REFERENCES}

[1] Liu Hongni, "The Lexicalization on na pa," Nankai Linguistics, 2010 (1): 142-150. (In Chinese)

[2] Zhang Xuemei, "The Lexicalization of na men zi and Related Issues,” 2015 (4): 8-14. (In Chinese)

[3] Zhu Dexi, Lectures on Grammar. Beijing: Commercial Press, 1982. (In Chinese)

[4] Lv Shuxiang, Eight Hundred Words of Modern Chinese Language. Beijing: Commercial Press, 1980. (In Chinese)

[5] Dictionary Editing Office, Institute of Languages, Chinese Academy of Social Sciences, Modern Chinese Dictionary (7th Edition). Beijing: Commercial Press, 2016. (In Chinese)

[6] Ferdinand de Saussure, Course in General Linguistics. Chicago and La Salle, Illinois: Open Court Publishing Company, 1986.

[7] Dong Xiufang, Lexicalization: The Origin and evolution of Chinese Disyllabic Words. Beijing: Commercial Press, 2002. (In Chinese)

[8] Dong Xiufang, "On the Lexicalization of X shuo," Linguistic Sciences, 2003 (3): 46-57. (In Chinese)

[9] Laurel J. Brinton and Elizabeth C. Traugott, Lexicalization and Language Change. New York: Cambridge University Press, 2005.

[10] Lu Bingfu, “The Synchronous Chunking Process of Sentence Comprehension and Its Quantitative Description," Studies of Chinese Language, 1986 (2): 106-112. (In Chinese)

[11] Feng Shengli, "Interactions between Morphology, Syntax and Prosody in Chinese," Beijing: Peking University Press, 1997. (In Chinese)

[12] Fang Mei \& Le Yao, "Conventionalization and Stance-taking in Chinese Discourse," Beijing: Peking University Press, 2017. (In Chinese)

[13] Shen Jiaxuan, “A Survey of Studies on Subjectivity and Subjectivisation," Foreign Language Teaching and Research, 2001(4): 268-275. (In Chinese) 